\title{
Strategies for Transformation of Higher Education Towards Enhanced Productivity in Nigeria - The Role of Quality Assurance
}

\author{
Dr. Okoro, Cecilia O. \\ Aguguam, Chigozie N. \\ Department of Curriculum Studies and Educational Technology \\ University of Port Harcourt
}

doi: 10.19044/esj.2017.v13n10p137 URL:http://dx.doi.org/10.19044/esj.2017.v13n10p137

\begin{abstract}
This paper $\mathrm{x}$-rayed the importance and linkage of education to the development of the Nigerian society. The quality of tertiary education as a system which serves as a mechanism of advancement in Nigeria is being confronted with the age-long difficulties of limited access, scarce financing, decreasing quality and relevance. The paper examines the rationale for the transformation of tertiary education system towards enhanced standard of education in Nigeria. This entails a shift to a more realistic approach that encourages the involvement of everybody's effort towards ensuring quality in Nigerian higher education. The concept, role and problems of art teaching and learning, role were discussed. The paper concludes that the state of tertiary education in Nigeria is poor and thus the need for new approaches to be utilised to turn the situation around for better. It thus recommended that there should be a complete overhaul of the mode of instruction, massive investment in infrastructures in higher education.
\end{abstract}

Keywords: Higher Education, Quality Assurance, Quality Education

\section{Introduction}

The essence of linking quality assurance to education is to facilitate educational transformation and enhance human productivity. For quality education to be successful in any nation, all the key players of learning which include the teacher, learners, instructional materials and environment must be arranged in a co-operative way. In other words, there must be enough teachers who are qualified and effective; also, the environment must be a motivating one to the instructors and students. Nigeria has tried to confront the challenge of illiteracy, incapacitated graduates, and ignorance, this is why both policies on education and human did not limit education to a 
particular citizen, tribe, class and gender. Even the on-going Universal Basic Education was established to ensure that every Nigerian citizen will enrol into free and needed education which is to be rich in quality and quantity at all times.

At present, there is an increase on the founding of several private educational institutions all over the nation. People's notion remains that quality education could be gotten from private institutions. This reveals that all the efforts of the government to ensure human development through education are still at the cross-road, hence the higher institutions are not yet transformed. Therefore, this paper will be treated under the following subheadings:

i. $\quad$ Concept of Higher Education

ii. Concept of Quality Assurance

iii. Higher Education at Present

iv. Quality Assurance: a Transformational Strategy

v. Challenges of Quality Assurance

\section{Higher Education in Nigeria}

Higher Education embraces all organised learning activities at the tertiary level. The National Policy on Education (2014) conceptualised tertiary education to embrace the universities, colleges of education, polytechnics and mono technics. The objectives of tertiary education are:

i. To add to national development through advanced significant manpower training;

ii. To cultivate and instil proper values for the survival of the society.

iii. To cultivate the intellectual proficiency of learners to comprehend and become responsive to their environments (local and external).

iv. To gain both technical and academic skills that could aid learners to be resourceful and beneficial members of the society;

v. Promotion and encouragement of grants and community services;

vi. To build and solidify national unity; and,

vii. To promote national and international understanding and institutions.

The Yaba Higher College became the premier institution for higher education established in Nigeria, in 1934. This was followed by the formation of the first University College Ibadan, in 1948. The education sector widened at the wake of Nigeria's independence in 1960, and more specific expansions in higher education as it done by geographical zones. In the light of her independence, the University of Nigeria, Nsukka was established in (1960), while Ahamdu Bello University, Zaria, University of Lagos, and the University of Ife were birthed in 1962, and much later, came the University of Benin in 1970 (Okemakinde, 2010). These institutions are 
called the first generation universities in recent times. Also, seven more universities were established in 1975 at Jos, Maiduguri, Sokoto, Kano, Ilorin, Calabar and Port Harcourt, which resulted from the creation of new states at the dawn of the oil boom and it was done according to geopolitical zones in Nigeria; in compliance with persuasive agitations from Nigerians for more institutions of higher learning in the newly created states. These institutions were called the second-generation universities.

Polytechnics and mono technics came in existence in Nigeria during the colonial era, which was before the emergence of universities with the aim of achieving high level technical manpower in a range of technical and professional disciplines. To accommodate the needs of the geographical zones, the federal government made the supply of facilities for technological education to be equal, likewise established federal polytechnics in many parts of the country. These institutions added greatly to meeting the social demands for tertiary education up till the middle of the 1990s. However, in contemporary times, there have been too many questions as regards to the appropriateness and relevance in the existing structure of things, as there is disillusionment amongst young learners with the state of polytechnic education in Nigeria. Affirming to this Okemakinde (2010) opined that, at the dawn of Nigeria's independence in the early 1960s, followed the establishment of the first Advanced Teachers' Colleges (mainly for turning out 'highly trained non-graduate teachers' mostly for secondary schools) in Northern region, Zaria, Eastern region in Owerri, Western region in Ibadan, and Mid-West region in Abraka. The formation of extra states in the federation, and the aggregate demand for teachers, (resulting from educational expansion in the country), brought about the setting up of more institutions, which recently are known as colleges of education, in each part of the country. A larger number of the institutions of higher learning is either federally or state government-owned. However, there exists a rapid increase in private colleges of education in recent years. Like polytechnics, the admiration of colleges of education is gradually declining, as they are no longer anybody's first choice. For this actual fact, there is every need for the government to take a cursory look at their original reason of being/establishment and come up with re-positioning process for them. Presently in Nigeria, all states have either a state higher institution or a federal one located there

\section{The Concept of Quality Assurance}

Quality as a term has no generally accepted definition, however, quality embodies a standard of a phenomenon. The concern for quality has remained a front burner as one of the strong reasons for positive changes in education. Ajayi and Adegbesan (2007) viewed quality as the total of the 
make-up of a process, product or service on its performance, in customer's or client's perception of that performance. It is not just the make-up of a complete product or service rather incorporates an emphasis on the internal procedures and outputs and comprises a decline of waste and the improvement of productivity. In line with the above definition, Fadokun (2005) characterised quality by three interconnected parts;

Efficiency in the meeting of its goals,

(ii) Significant to human and environmental settings and needs,

(iii) Something more" which means the search for new ideas, the quest for excellence and encouragement of creativity.

In line with education, the International Institute for Educational Planning (IIEP) viewed quality from different perspectives. The first is from the internal criteria of the system such as profile expiration and the external criteria which are the fitness and the bearing of such an education on its environment. Quality in education should be based on its strength to support the sound performance of student's in standard examinations, likewise being relevant to the needs of the students, community and society large. Conversely, quality assurance is linked to quality control; however, it plays a strategic role as it relates to quality control, and functions on chains of operational procedures which ensure that prerequisite are achieved. Quality assurance spreads out to accommodate the processes that produce the products. In affirmation, Ajayi and Adegbesan (2007) conceptualised quality assurance to be linked to accountability as they are concentrated on getting the most out of educational systems and services as it points to effectiveness and efficiency in contexts, missions and stated objectives. Ehindero (2004) was right when he said that quality assurance centred on the:

(i) Learners entry behaviours, characteristics and attributes comprising some demographic elements that can obstruct or aid their learning,

(ii) The teacher entry qualification, values, pedagogical skills, professional preparedness, subject background, philosophical orientation etc.

(iii) The teaching/learning processes which comprise itself with the organisation of the curriculum and learning environment,

(iv) The outcomes, which is distinct for different levels in terms of knowledge, skills and attitudes including appropriate and relevant instruments to assess these objectives.

From the above meaning, quality assurance comprises all approaches, objectives, actions and procedures that consolidate adequate academic standards when used appropriately in line with quality control activities. Fadokun (2005) encapsulated the definition of quality assurance to be a programme, an institution or a whole education system

Quality Assurance has been summed up by diverse authorities like Okebukola (2008) stated that quality assurance deals with the policies, 
systems, strategies and resources used by the institution to satisfy itself so that its quality requirements and standards are being met. Also, Oladosu, (2012) stated it as the process of monitoring quality and ensuring that standards are not only continuously sustained but also improved upon. According to him, it entails continuous assessment, evaluation, maintenance and improvement of quality by an institution, a programme or a higher education system. It invariably means that quality assurance has a continuous nature, prone to improvement and the wide-ranging appeal of quality assurance. The perception of quality assurance involves the University input-Process, University output-Students, teachers, non-teaching staff, managers, curriculum, facilities, finance, institutional materials, other resources. He went further to include teaching and learning, research, use of time and space, student services, administration, leadership, community participation, skilled and employable graduates, responsible citizens, economic development, production of knowledge as they are extra to a process (Ojerinde, 2008).

\section{Internal Quality Assurance}

In the opinions of Oladosu (2012), the policies, mechanisms, processes and certainly the attitudinal changes form a congruent which when effected internally (by the institution) to guarantee compliance with standards, accountability and fitness of purpose, it is seen as internal quality assurance. For example, during accreditation by the National Universities Commission (NUC) in some Nigerian universities, the Academic Planning Department is wholesomely evaluated and monitored through a step by step process while the remaining is done by self- study instruments by Colleges, the Registry, the Bursary and other units. The activities of internal quality assurance involves stages that are meant to appraise the system and likewise its processes to determine the weaknesses and possible remedial measures for possible solutions. The normal situation has been the non-follow-up attitude of NUC in the constant appraisal of universities internally thereby making the universities to feel reluctant and wait for another accreditation under a hasty mode. Recently, internal quality assurance activities only get attention when NUC accreditation exercises are forthcoming and are quickly left aside after the statutory exercise. This gap is rewarded for in the form of the institutional dropping of the guard, drop in standards and scholarship and when such falloffs accrue over time they place universities on the table of uncertainty in terms of suitability for teaching, learning and research.

\section{External Quality Assurance}

This refers to the monitoring and evaluation for agreement with stipulated rules and standards carried out by statutory agencies from outside 
the university. It scrutinises the appropriateness of purpose and effectiveness of the internal quality assurance processes used by the statutory agency, with an examination of the system's structure, its documentation and the evaluation of quality done by the entity. Also, it examines the compliance of tertiary institutions with requirements of license holders under these regulations, where appropriate; likewise, any conditions or restrictions imposed. It comprises suitable investigatory mechanisms to guarantee financial probity, the legal representative and the persons occupying a leadership position are right and suitable persons to deliver extra on higher education programmes.

For example, new universities in Nigeria, submit to resource verification exercises and undergo appraisal of their temporary operating licence as this is to monitor compliance with prospects and the possibility of issuing of the permanent operating licence. Also, both old and new universities go through periodic accreditation of their programmes by the NUC through selected panels of renowned professors. The exercise creates an all-inclusive evaluation of institutional vision, mission and strategic goals, teaching quality, learning and research, institutional efficiency and effectiveness, institutional resources, institutional control and management among others.

\section{Higher Education Quality at present}

Educational quality can be seen in terms of the inputs, processes and outputs. The mobilisation of human and financial assets in education should be in agreement with a society's commitment to providing high quality educational experiences for every person. The value of any educational system as an investment rests on its fitness to constantly attend to the needs of its stakeholders better and remain relevant (Ijaiya, 2001),

The vision bearers of education (the leaders) dictate its quality at the local, state and the nation levels. Unarguably, that vision must have an eagle eye to see education as a program that covers honest and transparent administration, delivery of suitable resources to people at local level, the training of instructors which must cater for the professional advancement of instructors in pre-service and for lifelong learning, subsequently ensuring a space with suitable materials and new technologies.

Curricula and pedagogy are two things that constitute teaching and learning at the tertiary level. The knowledge-based economy has been made too competitive in recent times; therefore, the continuous updating of the curricula is a never-let-go task. Clark (2001) averts that tertiary institutions must modify their curricula every two or three years so as to guarantee that the content of their teaching reflects the fast-evolving frontiers of knowledge. From the viewpoint of pedagogy, extended access and higher 
involvement rates show that the population of students will increase rapidly in areas of their educational training, capacities, spur and benefits.

In Nigeria, there are three clear cut marks that submit to the prerequisite for more attention to innovation in both curricula and pedagogy. Firstly, the success of students appears to be narrow and the rate of dropouts seems to be high. However, the institutional statistics lacks validity and tertiary institutions do not appear to observe their dropout rates. In 2002, the NUC tried to compute dropout rates within the federal university organisation and its initial findings showed that dropout rates were as high as 30\% (NUC, 2002).

Secondly, the employers of labour (public and private) including the government, sees the worth of graduates from tertiary institutions as insufficient. After a study was conducted on graduates in the labour market, results showed the belief of employers in the poor training of tertiary institutions graduates and their unproductivity ability on the job, and the inadequacies are mainly severe in oral and written communication, and in applied technical skills (Dabalen, Oni \& Adekola, 2001). Thirdly, the curricula of the tertiary institutions are deficient in quality (NUC, 2002).

In the opinions of Oni (2000), the causes that are responsible for the poor quality of tertiary institutions programs (including graduates) seem to be both internal and external to the institutions. The internal factors are summed up with absence of employees' motivation, strikes and weak accountability for educational performance while the external factors involves corruption, lack of teachers', and the uneven funding efforts by government, likewise the use of quota system in admissions instead of merit

Quality control practices in Nigeria education principally centres on educational supervision, monitoring and control. West-Burnham (1994) opined that although such measures are fitting for gaining data for the implementation of policy and strategic planning, and assist in public accountability, they seem minute in value as it concerns the organisation of the classroom learning processes. Similarly, some remedies are required for the effective planning and utilisation of such facilities, as its provision and rehabilitation (school facilities) support in the delivery of quality, in the teaching-learning process.

The value of any management is centred on its strength to produce quality products and satisfy clients and other stakeholders. Its responsibility, consequently, embraces the identification and solving of any problem which hinders quality delivery. Such a problem-solving method should be resolute on taking preventive measures against wastage. The identification of learners' needs should be an all-inclusive effort, as problems are identified and the primary causes addressed (Ijaiya, 2001). 


\section{Quality Assurance: A Transformational Strategy}

In this jet age, the topmost advantage of quality assurance is assured quality and, all should be geared towards the assurance of quality of Nigerian universities as a unique product. Nigeria has about 124 approved universities with various proprietary arrangements, i.e., Federal Government, State Governments and Private proprietors (NUC, 2002). The nonexistence of internal and external quality assurance measures will lead to the disappearance of the aims of producing experienced, skilled and proficient manpower that will be in the governance of the country to be an illusion thereby compromising development drastically.

The benefits of quality assurance are unimaginable as it include among other things;

a. The upholding the reliability of programmes and the worthiness of the certificates issued by higher institutions of learning.

b. Providing confidence to teachers themselves.

c. Quality assurance makes universities to be competitive both nationally and internationally. Every university is mandated to teach and do research and mainly, the making of high-level manpower that is wellorganized, rational and intellectually developed to change the world".

d. Quality assurance measures and strategies determine the proper aligning of a given university on a right path and the availability of the drive to develop on output and finally become better if not best.

e. Quality assurance keeps students away from substandard quality programmes, poor curriculum delivery and from unfriendly academic environments.

Also, the strategic use of quality assurance in the changing of higher education quality in Nigeria could be seen in the following ways;

i. $\quad$ Helping to determine the quality of teachers' input.

ii. Assist in the monitoring and supervision of education activities especially that of teaching and learning.

iii. Helping to determine the resources likewise the facilities needed for smooth operations especially that of teaching from time to time.

iv. Assisting in determining the adequacy of the learning environment for the comfort of both the teacher and the students.

v. Ensure that available financial resources could be wisely and carefully used (Adegbesan, 2012).

These profits, among others, are vital to quality academic supply, allround students' academic transformation and the learning of professional ethics, socio-economic significance and the placing of standard in institutions.

A vital requirement of quality assurance is that it can be practised at every level of the university, as accountability in the school system is the 
responsibility of anyone involved in education. This means that everybody at all levels is involved when it comes to quality assurance; (academic and nonteaching staff) the security, works, Bursary, departments among others. The axiom that no education can increase above its teachers is relevant here. Quality assurance should be in the lime-light of every educational policy and beyond if the objectives of higher institutions are to be achieved and for the actualization of Nigeria's goals of economic independence more so in the present knowledge-driven economy.

\section{Challenges of Quality Assurance}

Adedeji and Bamidele, (2003), the alarming rate of ineffectiveness of teachers (inputs) in the profession of teaching has led to substandard students (products) and it has extended to graduates who are unemployed and unfit to be placed on any job as an outcome of their half-baked nature, is not a welcomed development. However, the dilemma situation is living among us.

In the views of Olaniyan and Okemakinde (2010), it is a negation to link the abysmal levels of literacy and school achievement to school related factors only as other factors like the home, the society, government and personal characteristics plays a vital role in education development. This is why the need for educational supervision and control is needed to be on ground and effective to checkmate the excesses and the residual functions of developing human capital by the education sector. Sadly, the inspectorate service has dwindled in their expectations at the federal and state levels. This is because the inspectorate service is plagued by a number of issues and challenges (Okugbe, 2010).

Okemakinde (2010) averred that the question of inadequate funding has remained a menace of the higher education in the country. The main source of these problems can be pointed to insufficient funding of the higher education system. For many years, funding shortfalls have been a reoccurring decimal as enrollments per year have increased more rapidly than the government's capacity to maintain its proportional financial support. Simply put, higher education system has handicapped with the financial resources needed to maintain educational quality in the midst of significant enrollment expansion

Much of higher institutions' teaching in Nigeria, agreeing with NUC (2002) assertions, states that, the old form of instruction (talk-chalk method) is been used in this jet age to deliver instruction to the learners, as such fails to catch-up with the government's own standards in many areas. Presently, the content and method of teaching in most Nigerian higher institution, is often obsolete, not in line with the demands of the labour employer (private and public). Similarly, the output of its research lacks value or will be very low as to meet up with the gains of innovation. 
Higher education system in Nigeria has steadily increased and surpassed Government carrying capacity (principal investor) of this growth. Below these circumstances, local income generation profits from extra significance and likewise serving as reinforce of policies that support decentralisation and institutional autonomy. In as much as revenues generated locally has appreciated gradually in recent years, it has come to its elastic point where what is expected will not be achieved with the existing situation (Johnston, 2002). Whether or not government agrees to endorse the increase of these tendencies in Nigeria, it will ascertain the possible outlook of higher education in the near future.

\section{Conclusion}

Educational transformations are constantly the result and the sign of social transformations in positions of which they are to be explained. The need for change in any educational system is to be complemented with new ideas which individuals would perceive as necessary. The educational state of Nigeria is visibly poor; however, some measures could be taken to turn the tide. The need has arisen for Nigerian education to be placed correctly. That is the lone way to sustainable development. Transformational teaching entails the outspreading of our anticipations for the influence that we, as teachers, could have in and outside the classrooms.

\section{Recommendations}

Governments and policy makers should strategize ways of refining the quality of education and teaching so as to improve students' academic achievement in higher institutions in Nigeria. The importance to do the needful for the improvement of learning includes:

$>\quad$ Massive investment in infrastructures at all levels of education

$>\quad$ Enhancing student- teacher friendliness in the school environment.

$>\quad$ Tracking of resources to solidify proper, adequate and accountable utilization of resources budgeted for education

$>\quad$ Upgrading of teacher's quality through employment of professional and qualified teachers and provision of in-service training and re-training.

$>\quad$ University law should institutionalize Quality assurance for effective monitoring, evaluation, sustenance and improvement of programmes and all other components and operations of tertiary institutions.

\section{References:}

1. Adedeji, S. O \& Bamidele, R. O (2003). Economic Impact of Tertiary Education on Human Capital Development in Nigeria In Human Resource development in African. Ibadan: The Nigerian Economic Society. 
2. Adegbesan (2012). School Management and Quality Assurance in Nigeria Education. Retrieved online 23/03/2017 from www.transcampus.org/.../Jorind\%20Vol11\%20No2\%20Dec\%20Cha pter23.pdf

3. Ajayi T, andAdegbesan S.O. (2007). Quality assurance in the teaching profession. Paper presented at a forum on emerging issues in teaching professionalism in Nigeria (14-16 March) Akure, Ondo State.

4. Clark, B. (2001). The entrepreneurial university: new foundations for colleagiality, autonomy and achievement. Higher Education Management, 13:2, 9-24.

5. Dabalen, A. Oni, B. and Adekola, O. (2001). Labor market prospects for university graduates in Nigeria. Higher Education Policy 14, 141159.

6. Ehindero, S. (2004). Accountability and quality assurance in Nigerian education. Paper presented at the international conference of the Institute of Education, Olabisi Onabanjo University, Ago - Iwoye. (Jan 12th - 15th).

7. Fadokun, J.B. (2005). Educational assessment and quality assurance implication for principal instructional leadership roles. Paper presented at the 31st Annual Conference of International Association for Educational Assessment 4-9 September, Abuja.

8. Federal Ministry of Education. (2004). National policy on education. Lagos. NERDC.

9. Ijaiya Y (2001). From quality control to quality assurance: A panacea for quality education in Nigerian Schools. In N.A. Nwagwu, E.T. Ehiametalor, M.A Ogunu and M. Nwadiani (Eds). Current issues in educational management in Nigeria: A publication of the Nigerian Association for Educational Administration and Planning. Benin City: NAEAP, 295-303.

10. Johnston, B. (2002). Financing higher education in Eastern and Southern Africa: diversifying revenue and expanding accessibility. Conference report of March 24-28, 2002. Buffalo, NY: Center for Comparative and Global Studies in Education,

11. National Universities Commission. (2002). Ranking of Nigerian universities according to performance of their academic programmes in 1999 and 2000. February. Abuja, Nigeria: NUC.

12. Ojerinde, D. (2008). "Quality Assurance in Nigeria University System: Assessment and Feedback Mechanism”, in Quality Assurance in Nigerian Universities, FUTA. 
13. Okebukola, P. (2010). "Quality Assurance in Nigerian University System”, in Quality Assurance in Nigeria University System, Fuwape and Ogunsemi, FUTA.

14. Okemakinde, T (2010). Determinants of Public Expenditure in Primary Education in Southwest Nigeria (1990-2004). Unpublished Ph.D thesis. University of Ibadan, Ibadan.

15. Okugbe ,E. (2010) Supervision of Universal Basic Education Centers in Anambra State, Nigeria: Concept, Challenges and Prospects. Awka: World Education Services

16. Oladosu (2012). "Quality Assurance in the University System”, in Practical Guide on Planning in Nigerian Universities: A Compendium of Academic Planning Tools, CODAPNU.

17. Olaniyan, D.A and Okemakinde, T. (2010). Quality Assurance in Rural Primary Schools in Nigeria. African Journal of Educational Management. 13(1). 61-70.

18. Oni, B. (2000). The demand for university graduates and employer's assessment of graduate skills in Nigeria.Ibadan, Nigeria: NISER. O'Sullivan, E. (2003) "Bringing a perspective of transformative learning to globalized consumption." International Journal of Consumer Studies, 27 (4), 326-330

19. West - Burnham, J. (1994). Inspection, evaluation and quality assurance. In T. Bush and J.West-Burnham (eds). The Principles of Educational Management, 157-176. Harlow: Longman 